\title{
Organizational innovation: a comprehensive model for catalyzing organizational development and change in a rapidly changing world
}

Annika Steiber ${ }^{*}$ and Sverker Alänge

\author{
* Correspondence: \\ annika.steiber@gmail.com \\ Department of Technology \\ Management and Economics, \\ Chalmers University of Technology, \\ SE-41296 Gothenburg, Sweden
}

\begin{abstract}
Previous research has found that organizational innovations are important for organizations' long-term competitive advantage and for technical innovations. In spite of this conclusion, organizational innovations remain poorly managed and poorly understood, especially the processes through which organizational innovations are created, diffused, and sustained. There is thus a need for a more comprehensive understanding of mechanisms catalyzing organizational development and change. The purpose of this paper is to develop a comprehensive model for studying and better understanding the creation, diffusion, and sustaining of organizational innovations by using a system perspective. The three concepts "creation," "diffusion," and "sustaining" are highly intertwined and should not be explored in isolation, as organizational innovations are constantly being re-invented.

The model for catalyzing organizational development and change could be visualized as five steps that form a circular pattern around an organizational-specific and pathdependent improvement trajectory rather than a single organizational innovation. The five steps are influenced by the external context, the internal environment, and the characteristics of the innovation itself. Further, different diffusion channels such as consultants, universities, and standardization forums function as mechanisms for knowledge transfer and triggering one or several of the five steps. The model is developed based on two literature reviews conducted over a 14-year period and findings from two empirical studies covering four Swedish manufacturing firms and one hospital.

The model proposed here has already been used in practice in a study for the Swedish Innovation Agency VINNOVA. Likewise the model proved to be useful in analyzing both similarities and differences between different national programs for catalyzing organizational development. This comprehensive model, we suggest, has a wider and more general use and is applicable across the Triple Helix model.
\end{abstract}

Keywords: Organizational innovation; Organizational development; Model; Creation; Diffusion; Sustaining

\section{严 Springer}

(c) 2015 Steiber and Alänge. This is an Open Access article distributed under the terms of the Creative Commons Attribution License (http://creativecommons.org/licenses/by/4.0), which permits unrestricted use, distribution, and reproduction in any medium, provided the original work is properly credited. 
Spanish: Innovación Organizacional: Un modelo comprensivo para catalizar desarrollo y cambio organizacional en un mundo que cambia rápidamente.

Resumen: Investigación previa ha demostrado que innovaciones organizacionales son muy importantes para la ventaja competitiva de largo plazo de organizaciones así como para su capacidad de innovación técnica. A pesar de esta conclusión, innovaciones organizacionales son muy pobremente administradas y estudiadas, y este es un problema especialmente agudo con respecto de los procesos de creación, difusión, y sostenimiento de innovaciones organizacionales. Existe por tanto la necesidad de un entendimiento más completo de los mecanismos que catalizan el desarrollo y cambio organizacional.

El propósito de este artículo es desarrollar un modelo comprensivo para el estudio de la creación, difusión, y sostenimiento de innovaciones organizacionales usando una perspectiva de sistemas. 'Creación', 'difusión', y 'sostenibilidad' son conceptos entrelazados y no deben estudiarse por separado porque las invenciones organizacionales son continuamente reinventadas. Un modelo para catalizar el desarrollo y cambio organizacional debe explicar la trayectoria de mejoras de una organización en lugar de explicar innovaciones, una por una a la vez. Por tanto, proponemos un modelo de cinco pasos que forman un patrón circular alrededor de la trayectoria de innovaciones. Estos cinco pasos son influenciados por el contexto externo, el ambiente interno, y las características de las propias innovaciones. Adicionalmente, varios canales de difusión como consultores, universidades, y fórums de estandarización, funcionan como mecanismos para la transferencia de conocimiento y como un mecanismo que activa uno o varios de los cinco pasos. El modelo es desarrollado en base a la revisión de dos literaturas que cubren un periodo de 14 años de publicaciones y los resultados de dos estudios empíricos que cubren cuatro manufacturas Suecas y un hospital.

El modelo comprensivo propuesto aquí ya ha sido usado en la práctica en un estudio de la Agencia de Innovación Sueca VINNOVA. Asimismo el modelo ha probado su utilidad en el análisis de similitudes y diferencias entre programas nacionales que promueven el desarrollo y cambio organizacional. Sugerimos que este modelo puede tener un uso más general y amplio y mostramos aquí como puede integrarse al modelo de la Triple Hélice. 
French: Innovation organisationnelle : un modèle global pour catalyser le développement organisationnel et le changement dans un monde en mutation rapide.

Résumé: Des études antérieures ont montré que les innovations organisationnelles sont importantes pour les avantages compétitifs à long terme des organisations et pour les innovations techniques importantes. Malgré cela, les innovations organisationnelles restent à notre connaissance mal gérées et mal comprises. Particulièrement les processus selon lesquels les innovations organisationnelles sont créées, diffusées et soutenues. Des recherches antérieures ont pourtant identifié le besoin d'une compréhension plus complète des mécanismes catalysant le développement organisationnel et le changement.

Le but de cet article est de développer un modèle global pour mieux étudier et comprendre la création, la diffusion et le maintien des innovations organisationnelles, en utilisant une perspective systémique. Les trois concepts « création 》, « diffusion 》, et « maintien » sont entremêlés et ne doivent pas être explorés isolément, étant donné que les innovations organisationnelles sont constamment réinventées. Le modèle catalyseur du développement organisationnel et du changement pourrait donc être visualisé comme cinq étapes formant un schéma circulaire autour de la trajectoire spécifique des innovations plutôt que d'une seule innovation organisationnelle. Les cinq étapes sont influencées par le contexte extérieur, l'environnement intérieur et les caractéristiques de l'innovation elle-même. En outre, différents moyens de diffusion par le biais des consultants, des universités et des forums de standardisation, fonctionnent comme des mécanismes de transfert des connaissances et déclenchent une ou plusieurs des cinq étapes. Le modèle est développé en partant de deux revues de la littérature scientifique sur une période de 14 ans et les résultats de deux études empiriques couvrant quatre entreprises industrielles suédoises et un hôpital.

Le modèle proposé peut être généralisé et est applicable à travers le modèle de triple hélice. II a déjà été mis en pratique dans une étude pour l'agence d'innovation suédoise " VINNOVA » et s'est montré utile pour analyser les similarités et les différences entre les différents programmes nationaux pour catalyser le développement organisationnel et le changement dans des organisations présélectionnées. 
Russian: Организационные инновации: сравнительная модель для катализирования организационного развития и изменения в стремительно меняющемся мире.

Аннотация: Предыдущие исследования показали, что организационные инновации важны для долгосрочной конкурентоспособности компаний и реализации технических инноваций. Несмотря на это, организационные инновации в нашем понимании остаются плохо управляемыми и слабо изученными. В частности, это касается процессов, посредством которых организационные инновации создаются, распространяются и поддерживаются. Ранее было показано, что существует потребность в формировании комплексного подхода к пониманию механизмов катализирования организационного развития и изменения.

Целью настоящего исследования является формирование комплексной модели для изучения и лучшего понимания создания, диффузии и поддержания организационных инноваций, учитывающей перспективы этой системы. Три концепции - «создание», «диффузия» и «поддержание» - достаточно тесно переплетены и не должны изучаться по отдельности, поскольку организационные инновации находятся в процессе постоянного обновления. Модель катализирования организационного развития и изменения может быть представлена как система из пяти циклически повторяющихся стадий, специфичных в части реализуемых траекторий для конкретной организации и зависящих от предшествующего пути развития, чем отличается от подхода на основе единичной организационной инновации. На эти этапы оказывают влияние внешнее и внутреннее содержание и характеристики инновации как таковой. Далее, различные диффузионные каналы, в частности консалтинг, университеты и отраслевые форумы, выступают в качестве механизмов трансфера знаний и инициируют один из пяти этапов. Модель разработана на основе двух литературных обзоров, охватывающих более чем 14-летний период наблюдений, и результатах двух эмпирических исследований, посвященных шведским производственных компаниям и одному госпиталю.

Сравнительная модель имеет более широкое и универсальное применение и может быть использована в рамках модели тройной спирали. Представленная модель была апробирована в рамках исследования деятельности Шведского инновационного агентства «VINNOVA», в котором подтвердила свою применимость для анализа сходств и различий национальных программам катализирования организационного развития и изменения в предварительно отобранных компаниях. 
Chinese: 组织创新:在迅速变化的世界催化组织发展与变化的一个综合模型 摘要

以往的研究发现:组织创新对组织的长期竞争优势非常重要,组织创新对于技术创 新也很重要。尽管如此, 就我们所知这世界还是缺乏组织创新和对组织创新的理 解。尤其是创造、扩散和持续组织创新的过程。因此,过去的研究需要改进, 以获 得对催化组织发展和变化的机制更全面的了解。

本文旨在从系统的视角开发一个综合模型, 以便研究和更好地理解组织创新的创 造、扩散和持续。当组织创新不断地被重新发明时，“创造”、“扩散”和 “持 续”这三个概念是高度交织的,不应当孤立地被探索。

因而,催化组织发展和变化的模型可被可视化为五个步骤。这些步骤围绕组织特 性和路径依赖改进轨迹而不是单一的组织创新形成一个圆形图案。它们受外部 环境、内部环境和创新本身的特点的影响。此外,不同的传播渠道,比如咨询顾 问、大学和标准化论坛等, 都作为知识转移机制起作用, 触发五个步骤中的一个或 几个。该模型是基于在14年期间进行的两个文献综述和涉及四个瑞典制造公 司、一家医院的两个实证研究开发出来的。

我们所开发的这个综合模型具有更广泛和更普遍的使用,适用于整个三螺旋模 型。它已经被用于为瑞典创新机构 “VINNOVA” 所进行的研究实践,并且被证 实有助于分析为催化预先选定组织的组织发展和变化的各种国家项目之间的相 似与不同。

Portuguese: Inovação Organizacional: Um Modelo Abrangente para catalisar o Desenvolvimento Organizacional e a Mudança em um mundo em rápida transformação.

Resumo: Pesquisas anteriores mostraram que as inovações organizacionais são importantes para a vantagem competitiva a longo prazo e para as inovações técnicas. Apesar disso, inovações organizacionais para nosso conhecimento permanecem pouco administradas e pouco compreendidas. Especialmente nos processos, através dos quais as inovações organizacionais são criadas, difundidas e mantidas. Pesquisas anteriores, portanto, identificaram a necessidade de uma compreensão mais abrangente do entendimento dos mecanismos que catalisam o desenvolvimento organizacional e a mudança.

O objetivo desse artigo é desenvolver um modelo abrangente para estudar e compreender melhor a criação, difusão e sustentação das inovações organizacionais, utilizando a perspectiva de sistemas. Os três conceitos "criação", "difusão" e "sustentação" são altamente interligados e não devem ser explorados de forma isolada, na medida em que as inovações organizacionais estão sendo constantemente reinventadas. O modelo para catalisar o desenvolvimento organizacional e a mudança poderia, portanto, ser visualizado como cinco etapas que formam um padrão circular em torno de uma trajetória dependente de um aperfeiçoamento organizacional específico, em vez de uma única inovação organizacional. Os cinco passos são influenciados pelo: contexto externo, contexto interno e das características da própria inovação. Além disso, diferentes canais de difusão, como consultores, universidades e fóruns de normalização, funcionam como mecanismos de transferência do conhecimento, desencadeando um ou vários dos cinco passos. O modelo é desenvolvido com base em duas revisões de literatura conduzidas ao longo de um período de 14 anos e de duas pesquisas empíricas que abrangem quatro empresas industriais suecas e um hospital suecos.

O modelo abrangente tem uma utilização ampla e geral e é aplicável no modelo da hélice tríplice. O modelo já foi utilizado na prática em um estudo para a Agência de Inovação sueca "VINNOVA" e mostrou-se útil para analisar as semelhanças e diferenças entre os diferentes programas nacionais que estimulam o desenvolvimento organizacional e a mudança de organizações pré-selecionadas. 


\section{Multilingual abstract}

Please see Additional file 1 for translation of the abstract into Arabic.

\section{Introduction}

This paper's focus is on organizational innovations and on how the creation, diffusion, and sustaining of organizational innovations can be conceptualized from a system perspective. Organizational innovations are here defined as new organizational methods in business practices, workplace organization, or external relations (OECD 2005).

Organizational innovations typically aim at increasing operational efficiency and employee satisfaction or at improving an organization's innovativeness. In fact, organizational innovations are often necessary for technical innovations (Freeman 1982; Leonard-Barton 1988; Tushman and O’Reilly 1997; Teece 2007; Volberda et al. 2013).

According to Ganter and Hecker (2014), many attempts at adaptation to environmental change are pertaining to organizational innovations. In a global marketplace, continuously changing due to rapid technological development, organizations need to make even more effective use of organizational innovations in order to uphold their competitiveness.

There are several examples of complex organizational innovations, such as Divisionalization ("M-form"), Total Quality Management (TQM), Toyota Production System (TPS), and Lean Production ("Lean"), that all have led to competitive advantages for the organizations that have embraced them (Womack and Jones 2003; Liker 2004; Birkinshaw et al. 2008).

However, in spite of the fact that organizational innovations create long-term competitive advantages and are important for technical innovations, they "remain poorly managed and poorly understood" (Birkinshaw and Mol 2006). One major reason is that most innovation research has focused on technical innovation, while research on organizational innovation has been conducted to a lesser extent (Birkinshaw et al. 2008; Ganter and Hecker 2013). Previous research has therefore identified a need to develop a more comprehensive model to better understand the mechanisms catalyzing organizational development and change (Frambach and Schillewaert 2002; Ganter and Hecker 2013 and 2014).

In order to increase our understanding of organizational innovation, the purpose of this paper is therefore to develop a more comprehensive model for studying the creation, diffusion, and sustaining of organizational innovations by using a system perspective.

The comprehensive model has a wider and more general use than organizational development and change of "firms." The model can also be used to explain and better understand the creation, diffusion, and sustainability of organizational change and development of most organizations, including governmental entities and universities. The model is therefore applicable across the Triple Helix model. The ambition of the paper is therefore to provide insights to practitioners in all three helices, firms, universities, and governmental entities, aiming at a more systematic approach to organizational development and change in their own organization in order to be competitive in a rapidly changing world.

The two following sections in this paper focus on Methodology and Literature review. The literature review covers two main parts; first, the concept of organizational innovation will be defined and explored, and second, previous research on how organizational innovations are created, diffused, and sustained will be presented. Findings from our 
empirical case studies presented in Alänge and Steiber $(2009,2011)$ are part of and integrated in the literature review. Next, a comprehensive model for studying the creation, diffusion, and sustaining of organizational innovations will be presented. Finally, the paper ends by presenting some key conclusions and recommendations for future research.

\section{Methodology}

This section introduces the different steps to develop a comprehensive model for the creation, diffusion, and sustaining of organizational innovations. The development of the model follows an abductive approach (Dubois and Gadde 2002), where an initial literature review resulted in a tentative analytical framework, that was subsequently tested in empirical studies providing inputs to refine the framework, which was contrasted to recent literature, ultimately resulting in the development of the comprehensive model presented in this paper.

Our starting point is a focus on organizational innovations and on how the creation, diffusion, and sustaining of organizational innovations can be conceptualized from a system perspective. Seminal work on understanding innovation from a system perspective has primarily been focused on technical innovation (Freeman 1987; Porter 1990; Carlsson and Stankiewicz 1991; Lundvall 1992; Nelson 1993; Etzkowitz and Leydesdorff 1995). ${ }^{1}$ The model for catalyzing organizational development and change presented in this paper originates from this line of research on technical innovation systems (Alänge et al. 1998) but has evolved through empirical research studies of complex organizational innovations such as TQM, Toyota Production System, and Lean conducted between 1993 and 2011 (Alänge and Jarnehammar 1995; Alänge and Steiber 2009, 2011). The process to develop the comprehensive model is described in more detail below.

First, an analytical framework for the diffusion ${ }^{2}$ of organizational innovations was developed (Alänge et al. 1998) based on a literature review conducted on the diffusion of both technical and organizational innovations (e.g., Kimberley 1981; Rogers 1995; Teece 1980) and with a strong influence of the then emerging literature on innovation systems (e.g., Carlsson and Stankiewicz 1991; Carlsson and Jacobsson 1994; Lundvall 1992). Taking the inspiration from theories developed for technical innovations, a major step was to identify characteristics of organizational innovation and how these potentially could influence the innovation and diffusion process. Thus, in the tentative framework issues to consider when analyzing the diffusion of organizational innovations were emphasized (Alänge et al. 1998).

Second, the analytical framework was then tested by applying it to the complex organizational innovation TQM, in two contrasting case studies of a professional kitchen manufacturing firm and a hospital. This resulted not only in the confirmation of the relevance of major parts of the assumptions and the concepts in the framework, but also in the refutation of some assumptions (e.g., limited "testability" and lack of "systematic search"). The result was an improved understanding and a modified analytical framework (Alänge and Steiber 2011). However, this study also identified one area that a previous theory to a large extent had omitted: the role of the governance structure above the CEO (boards and owners) when it comes to the diffusion and sustaining of complex organizational innovations.

Thus, the roles of boards in sustaining the three major organizational innovations TQM, TPS, and Lean were then explored in Alänge and Steiber (2009), once again with 
a longitudinal perspective covering time periods of 10-20 years in three different empirical cases analyzed (a steel company, a truck manufacturer, and a hospital). As had been assumed, the importance of the board level for sustaining organizational innovations was empirically verified and Alänge and Steiber (2009) showed that theories (e.g., agency theory) and perceptions of the relationship between board and CEO can potentially influence the sustainability of organizational innovations.

In order to further develop the framework, the findings from these empirical studies (Alänge and Steiber 2009, 2011) were then contrasted to and discussed in relation to other more recent research on the creation, diffusion, and sustaining of organizational innovation from a system perspective (e.g., Frambach and Schillewaert 2002; Buchanan et al. 2005; Birkinshaw et al. 2008; Ganter and Hecker 2013). This second literature review broadened the focus on both the creation and on the sustaining of organizational innovations and confirmed the view that the three concepts creation, diffusion, and sustaining are intertwined (Steiber 2012).

Subsequently, by including the broadened focus on "sustaining of innovations" in a study for the Swedish Innovation agency "VINNOVA," the framework was used for a comparative analysis of seven European and North American programs for the dissemination of organizational innovations (contributing to innovativeness and increased competitiveness among existing firms). This study showed that the model was also useful in analyzing both similarities and differences between the seven different national/ international programs (Steiber and Alänge 2013a).

Finally, by integrating the findings from the literature reviews with findings from the empirical cases (Alänge and Steiber 2009, 2011; Steiber and Alänge 2013a), the comprehensive model for studying the creation, diffusion, and sustaining of organizational innovations was developed in this paper.

\section{Literature review}

In spite of the fact that organizational innovations have been found to be important for organizations' long-term competitive advantages, the creation and diffusion of organizational innovations have been subject to less research focus compared to technical innovations (Edquist 1992; Birkinshaw et al. 2008; Ganter and Hecker 2013). Further, the question of how to sustain an organizational innovation once implemented has received even less research attention, so that there is currently no established research tradition in this area (Buchanan et al. 2005). In order to better understand how organizational innovations are created, diffused, and sustained, this literature review consists of three main parts. First, the concept of organizational innovation will be defined and explored. Second, previous research on how organizational innovations are created and diffused will be presented. Third, previous research on how organizational innovations are sustained will be presented.

\section{Organizational innovation}

An organizational innovation ${ }^{3}$ can according to $\operatorname{OECD~}(2005, \mathrm{p}$. 51) be defined as:

A new organisational method in business practices, workplace organisation or external relations. Organisational innovations can be intended to increase an organization's performance by reducing administrative costs or transaction costs, 
improving workplace satisfaction (and thus labour productivity), gaining access to non-tradable assets (such as non-codified external knowledge) or reducing costs of supplies.

The above can serve as a general definition of organizational innovation. Within the concept of "business practices," we include organizational elements such as leadership, management processes (e.g., reporting and budget processes), culture, human resource management, mechanisms for learning, and external and internal corporate communication. Organizational innovation can refer to either "new-to-the-state-of-the-art" meaning that it has no known precedent or "new to the specific organization" (Mol and Birkinshaw 2009). In line with the OECD (2005), in this paper, we consider organizational innovations as "new to the organization."

Further, organizational innovations can vary in complexity. Some affect a certain business process (such as re-engineering the purchasing process), while others affect every single part of an organization. According to Hamel (2006, p 74), an organizational innovation creates long-term competitive advantages if it meets one or more of three conditions:

The innovation is based on a novel principle that challenges management orthodoxy; it is systematic, encompassing a range of processes and methods; and it is part of an ongoing program of invention, where progress compounds over time.

The three organizational innovations (TQM, TPS, Lean) investigated in the empirical studies utilized for this paper (Alänge and Steiber 2009, 2011) could all affect every single part of an organization and also fulfill Hamel's (2006) three criteria.

\section{The creation and diffusion of organizational innovations}

Four primary perspectives have been used when studying organizational innovations (Birkinshaw et al. 2008, p. 827). These are the institutional perspective where institutional conditions influence the creation and diffusion of organizational innovations, the fashion perspective where fashion setters continuously redefine both their and fashion followers' collective beliefs about which management techniques lead to rational management progress, the cultural perspective where the organization's culture influences the creation and diffusion of organizational innovations, and the rational perspective where managers take on a role in creating and implementing organizational innovations. In addition to these four perspectives, a fifth perspective was used in Alänge et al. (1998). This is the perspective of innovation systems, which in turn is partly influenced by the institutional perspective (e.g., Lundvall 1992). According to Birkinshaw et al. (2008), the research community has tended to use one of these different perspectives, or a combination of them (e.g., Kimberley 1979; Birkinshaw et al. 2008), when studying organizational innovations. This paper is primarily based on a combination of two perspectives: the rational perspective (Birkinshaw et al. 2008) and the innovation systems perspective (Alänge et al. 1998). The main reason for this is the belief that managers take on a leading and at least "bounded rational" (Simon 1979) role in the creation, diffusion, and sustaining of an organizational innovation, and the innovation systems perspective is useful in terms of better understanding the three concepts, 
specifically when the innovation systems perspective (most commonly focused on inter-firm/organization diffusion of innovations) is complemented with literature dealing with intra-firm/organization diffusion and change management in general (Alänge et al. 1998).

\section{Creation of organizational innovations}

Several attempts have been made to explore the concept "creation of organizational innovations" (e.g., Birkinshaw and Mol 2006). In the Birkinshaw et al. (2008) model ${ }^{5}$ the creation of organizational innovations is influenced by four sets of factors: the environmental context, the organizational context, and external and internal change agents. The environmental context is described as: "The broad set of stimuli - exogenous to the focal organization - that shapes the management discourse and thereby influences the priorities and efforts of external change agents as they engage with organizations." (p. 833). The organizational context is the: "Administrative and social mechanisms that management can manipulate to shape the behavior of actors in the organization ... and will have a direct impact (positive or negative) on the ability of internal change agents to pursue the core activities associated with management innovation." (p. 833). External change agents are considered to be: "Management intellectuals, idea entrepreneurs, independent consultants, academics and gurus proactive in creating interest in, influencing the development of, and legitimizing the effectiveness and retention of new management practices." (p. 832). Finally, internal change agents are considered to be: "Employees of the innovating company proactive in creating interest in, experimenting with, and validating the management innovation in question" (p. 832).

Ganter and Hecker (2013) compared their findings on antecedents of organizational innovation with the model developed by Birkinshaw et al. (2008). Ganter and Hecker emphasized the importance of factors in the organizational context and what they labeled "knowledge-based relations," which could be interpreted as the external and internal change agents in the model of Birkenshaw et al. However, Ganter and Hecker (2013) also saw a need to extend the Birkinshaw et al. (2008) model with factors characterizing the firm's competitive environment such as the intensity of competition, the speed of technological change, and the brevity of the product life cycle.

The Birkinshaw et al. (2008) model consists of four steps: motivation, invention, implementation, and theorizing and labeling. The "motivation" step is concerned with factors that create the motives, and thereby the desirability, to change the organization. The next step, "invention," involves experimentation. This step includes activities such as developing a solution, thinking through the consequences of the new idea, linking the idea to empirical data, and testing it in practice. The following step, "implementation," covers all activities after the test until the new innovation is fully operational. Finally, the last step, "theorizing and labeling," aims to build a rationale for why the innovation should be adopted, giving the innovation a name and communicating the rationale and the innovation internally as well as externally. Kimberley (1979) found that the first "release" of the innovation puts important constraints on later developments of organizational innovations. This finding means that the original innovation and later re-inventions of that innovation are path-dependent; in other words, the initial "release" of an organizational innovation will shape later releases of it. However, Lounsbury and Crumley (2007) comment upon that latter stages of practice creation, 
where new sets of activities are theorized (in order to facilitate their spread), tend to be emphasized, bracketing the earliest moments when the possibility of a new practice first emerges and is recognized as an opportunity for some social group. They therefore argued for a more comprehensive institutionalist approach to the problem of practice creation that extends the scope of analysis to organizational activities and processes that occur prior to theorization efforts and diffusion-driven taken-for-grantedness.

As with technical innovations (Rosenberg 1976; Ehrnberg and Jacobsson 1991; Rogers 1995), earlier research (Alänge et al. 1998) ${ }^{6}$ found that the creation and diffusion of organizational innovations formed two intertwined concepts, which made it hard to study the creation of organizational innovations separately from their inter-firm and intra-firm diffusion. However, Birkinshaw et al. (2008) explored the creation of management innovations without considering diffusion. Consequently, they defined management innovations as "new-to-the-state-of-the-art," rather than "new to the firm," and stated that the literature on inter-firm diffusion is of limited value for explaining the creation of management innovations. This would indicate that the process of creating management innovations starts more or less inside the boundary of the firm or other organizations, rather than within an innovation system. This is surprising, since Birkinshaw et al. (2008) discussed the importance of the external context and external change agents.

However, when the Alänge et al. (1998) analytical framework was tested empirically to study the diffusion of organizational innovations, a number of theoretical assumptions proved to be incorrect, and new findings were identified (Alänge and Steiber 2011). First, due to the tacit nature of organizational innovations, two aspects were found to be important with regard to the innovation itself. First, as assumed in Alänge et al. (1998), the separation between the innovation process and the diffusion process was even less relevant for organizational innovations than for technical innovations. Second, organizational innovations were re-invented (Rogers 1995) and standardized (Alänge et al. 1998) while diffusing. The organizational innovation was therefore continuously re-invented through the inter-firm and intra-firm diffusion processes. This observation is also in contrast to the static definition of organizational innovation by the $\operatorname{OECD}(2005$, p. 53), which makes the following comment on the meaning of organizational innovations:

Changes in business practices, workplace organisation or external relations that are based on organisational methods already in use... are not organisational innovations ... However, organisational changes that are implemented ... are an innovation if they represent the first implementation of a new organisational method in business practices, workplace organisation or external relations.

Furthermore, Alänge and Steiber (2011) found that the standardizations of the innovation itself, as well as of its implementation, were enacted at both national and firm/organization levels. Bridging institutions and consultants (Bessant and Rush 1995; Wright et al. 2012) were found to play an important role in the process of standardizing (or re-standardizing) the organizational innovation at the national level, while early adopters influenced the initial standardization of the innovation at the level of the firm/ organization. In comparison, Ganter and Hecker (2013) did not find that market sources (consultants) were important, while professional sources (industry organizations, 
professional associations, etc.) played a major role among knowledge-based relations in their German sample.

\section{Diffusion of organizational innovations}

The model by (Birkinshaw et al. 2008, p. 832) is similar to the diffusion model developed in Jarnehammar (1995) and used by Alänge and Steiber (2011), which focused on both the inter-firm and intra-firm diffusion processes of organizational innovations. Jarnehammar's (1995) model included four steps in the diffusion process: desirability, feasibility, first trial, and implementation. Desirability, feasibility, and first trial are covered in Birkinshaw et al.'s (2008) motivation and invention steps, while the implementation step is similar between the two models. The main difference between the two models is the theorizing and labeling step (Strang and Meyer 1993), which is not presented as a step but is covered by the term "standardization" in the model presented by Jarnehammar (1995). The close match between the two models, which had different purposes, is perhaps not surprising as Birkinshaw et al. (2008) implicitly included thoughts of both inter-firm and intra-firm diffusion in their model.

So, what can be learned from studies on the concept of the diffusion of innovations? Previous studies on this subject focus largely upon the diffusion of technical innovations, while scholars have less frequently studied the diffusion of organizational innovations (Teece 1980; Rogers 1995; Lynch 2007; Birkinshaw et al. 2008). This gap in the research literature has therefore been emphasized as an area to be addressed (Lynch 2007; Birkinshaw et al. 2008).

Already, Teece (1980) raised the question of whether the diffusion of organizational innovations is characterized by the same considerations as the diffusion of technical innovations, and if so, it might be possible to re-use lessons from the area of the diffusion of technical innovations. However, organizational innovations have some intrinsic features that are quite different from those of technical innovations (Alänge et al. 1998). Organizational innovations are more tacit in nature than technical innovations; there is no traditional market for organizational innovations, and no traditional calculation model for calculating return on investment for organizational innovations. Further, although organizational innovations commonly affect the daily work situation of many people in an organization, companies rarely have a formal position or formal strategies in place for organizational innovations as they would an R\&D manager and R\&D strategies for technical innovations. As a result, the market mechanisms function poorly, the search and learning processes may be less conscious and systematic, standardization of the innovations is based on subjective interpretations of early adopters, and top management commitment and the process of intra-firm diffusion of organizational innovations become more important than in the case of technical innovations.

In spite of the intrinsic feature differences identified, Alänge et al. (1998) concluded that insights from studies on technical innovations could be effectively applied to a study of the diffusion of organizational innovations. However, Alänge et al. (1998) drew a number of implications for the study of the diffusion of organizational innovations. Due to organizational innovations' higher degree of tacitness, they are less observable and testable compared to technical innovations, especially if the organizational innovation is also complex-for instance, if it affects many parts of the organization. In addition, organizational innovations can be assumed to affect a higher number of 
people and are harder to evaluate, as there is no traditional financial calculation method in the case of this type of innovation. As a result, the process of standardization, top management support and "belief" in the relative advantages, and compatibility between the new innovation and previously adopted innovations play a more important role for organizational innovations than for technical innovations.

Further, the interdependence between innovations, the subjective determination of boundaries around an innovation, and the continuous re-invention of the innovation are all more relevant to consider compared with the case of technical innovations (Alänge et al. 1998). Further, networks play an important role in both cases for the diffusion of innovations (Frambach and Schillewaert 2002); however, in the case of organizational innovations, interpersonal networks are the main channels for diffusion. Due to a lack of a traditional market, the local institutional setup, user networks, consulting firms, and movements of people all play an important role for the diffusion of organizational innovations.

When testing the Alänge et al. (1998) analytical framework empirically, Alänge and Steiber (2011) found that the internal context was influential in several ways. To begin with, the characteristics of the search and learning processes for organizational innovations were indeed cumulative and path-dependent, and also conscious and systematic, and affected both by the local environment and by international "weak ties" (Granovetter 1973). Each organization initially focused on sub-components that were most familiar to them, which created a form of inertia through interdependences with earlier or parallel organizational innovations. The finding that the search and learning processes were conscious and systematic, local and international, was contrary to the original assumption in Alänge et al. (1998). Further, the perceived organizational distance affected the search and learning processes in two ways. First, a large organizational distance blocks the initial perceptions of desirability and feasibility. Second, a large organizational distance at a process level hinders diffusion during first trial and implementation.

Moreover, inertia and resistance towards the organizational innovation constitute an influencing factor, but were not found to exist to any larger extent than in the case of technical innovations. Some explanations for this refer to the commitment of, and communication from, top management and the use of pilot studies of sub-components. Such use of pilot studies contradicts Teece's (1980) assumption that an incremental implementation is less likely for organizational innovations. The organizational innovation in our studies was later adjusted to the local context, based on experiences from pilot tests and the implementation process. In addition to lowering the transfer and implementation costs, the standardization also decreased resistance towards the change among the organizational members.

In addition, due to the possibility of observing and testing the innovation, or part of it, the transfer and implementation costs were perceived as manageable. On the other hand, decision criteria for investing in an organizational innovation were not discussed in the selected theoretical literature. However, based on the empirical findings in Alänge and Steiber (2011), the assumption that there is a lack of more traditional calculation models for investments in organizational innovations seemed to be correct. The decision to invest was instead influenced by a number of triggers during different steps in the diffusion process. For example, the desirability was influenced by demand from the corporate group management, perceived crises, fads, awareness of role-model 
organizations (such as Toyota), market demands, the work of national bridging institutions, and user networks, while perceived feasibility was influenced by aspects such as user networks at a low organizational distance, previously adopted organizational innovations, the CEO's previous experience, and the work of national bridging institutions. The final decision to test and later implement the innovation was then primarily based on the CEO's belief in the benefits of the organizational innovation. This belief had to be sustained in order to sustain the innovation. In the empirical studies, the top managements' beliefs persisted over time, but theoretically this belief could also have been negatively affected by the same triggers as those that created the desire and feasibility for the innovation, or by unreasonably high internal inertia.

The external context, or in Rogers' (1995) words, "the social structure," was found to influence the rate of diffusion of organizational innovations. The institutional setup, the existence of international and national fads (Abrahamson 1996), the existence of new market needs, the presence of consulting firms and non-market-mediated interpersonal contacts through user networks (which include links to firms/organizations at a limited organizational distance implementing the same innovation), and movement of people all influenced the rate of diffusion of a major organizational innovation and substituted a traditional market. As a consequence, individuals' networks, such as with standardization and industry organizations, companies that already had adopted the innovations, and people with experience of the innovation, played a profound role in the case of organizational innovations (Rogers 1995; Alänge and Steiber 2011).

However, the inertia and path dependency of the external context itself also influenced the rate of diffusion. The importance of local norms and historical experience has been emphasized by Rogers (1995), as well as research focusing on national and regional innovation systems (Lundvall 1992; Saxenian 1996; Cooke 2001). According to Rogers, relatively few studies have been conducted on how the social structure affects the diffusion of innovations; thus, both the local institutional setup and the importance of norms and historical experience on a nation and/or region's innovativeness should be considered in a conceptualization of the creation, diffusion, and sustaining of organizational innovations. In addition, there is an interaction between technical systems/artifacts and social systems that affects all change processes (Cummings and O'Connell 1978; Tichy 1983; Langstrand and Elg 2012; Bayerl et al. 2013), and it has been emphasized that the cultural and political systems and the technical design (social and technical systems) need to be considered simultaneously (Tichy 1983; Alänge 1992). Hence, both the setup and inertia of the local innovation system and individual firm/organization characteristics, such as user competence and top management behavior, play important roles for unlearning/learning in the diffusion of organizational innovations (Alänge et al. 1998).

\section{Sustaining organizational innovations}

Sustaining an organizational innovation emphasizes that a firm or organization should maintain a particular organizational innovation for a certain time period, which could be a sign of inertia (Buchanan et al. 2005). However, as pointed out above, innovations are constantly re-invented, and thus the concept of "sustaining" has to be elaborated upon. According to Buchanan et al. (2005), sustaining could refer to an improvement trajectory, rather than to a particular organizational innovation. According to the 
authors, this implies a more dynamic perspective on sustaining organizational change. The static view of sustaining a particular organizational innovation would then be only temporarily relevant.

After conducting a review of the literature on sustaining organizational change, Buchanan et al. (2005) identified four sets of factors that all play a role: 1) external context that includes factors such as turbulence and uncertainty in the external environment; 2) internal context that refers to a firm's history and therefore its receptiveness to change; 3) substance of change (e.g., whether the organizational innovation is perceived as important for the firm), change process and timing; and 4) seven organizational factors (managerial, leadership, cultural, organizational, individual, political, and financial) that influence sustaining (factors that can be configured and interact in different ways). The relative importance of each set (and each factor within each set) was not identified by the authors, but Buchanan et al. (2005) emphasized that the interplay between the factors plays an important role.

Buchanan et al. (2005) identified a number of factors similar to those found in studies on the creation and diffusion of organizational innovations. The external context and the firm's inertia and path dependency seem to play a role in all three processes. In addition, the innovation's perceived importance for the organization and the timing of the innovation matter in all three processes. Two aspects are partly new in Buchanan et al.'s (2005) model: first, the change process as such, which was not discussed by Birkinshaw et al. (2008) and was discussed only indirectly as an issue of standardization in the "implementation" step in (Alänge et al. 1998); and second, the external turbulence and uncertainty, which was identified as an inhibitor for sustaining an organizational innovation. The latter finding is of interest, as it could mean that it would be harder for a firm to sustain a particular organizational innovation in a rapidly changing industry than in a case in which the industry is more mature. This in turn means that the focus would be on an improvement trajectory, instead of a particular organizational innovation, which could be of even higher relevance for firms in rapidly changing industries and could therefore fit well with the ideas regarding the constant renewal that is necessary in rapidly changing industries developed by Brown and Eisenhardt $(1997,1998)$. Sustaining of a particular organizational innovation therefore can only be temporal and seems to be less relevant in rapidly changing environments.

The improvement trajectory can be viewed as a number of synergistic and complementary organizational innovations, since the firm and its search and learning processes are path-dependent. For this reason, the initial innovation puts constraints on later development within the organization (Kimberley 1979). In the event that a later implemented organizational innovation is not synergistic with, or complementary to, the already-implemented innovation, the new innovation might be seen as the start of a new improvement trajectory. Standardization, road maps, and narratives could be used to either strengthen a certain trajectory or communicate and make sense of a new direction (Shiba et al. 1993; Alänge 1994; Berendse et al. 2006). At certain points in time, influenced by external and internal changes, it could be assumed that a given trajectory is partly (or totally) broken, and therefore partly (or fully) exchanged with a trajectory that has a new goal, and therefore a new direction-for example, if a firm changes its focus from cost-cutting to innovation. However, the shift from one trajectory to another can be very problematic when the values/beliefs, skills, practices, and systems 
that were once core capabilities turn into core rigidities (Leonard-Barton 1992), and there is also a need to consider the role of unlearning to catalyze learning processes in order to change beliefs and routines in organizations (Akgün et al. 2007).

Alänge and Steiber (2011) found that the importance of top management involvement and visible support in order to implement organizational innovations was of greater magnitude than in the case of technical innovations, as a major organizational change takes years to implement and affects a large number of people within the organization. However, top management commitment alone was not enough for sustaining an organizational innovation. Alänge and Steiber (2011) also identified the need for a more long-term view in order to sustain organizational innovations-a view that goes beyond the time that the average CEO stays at the helm.

This observation pointed to the importance of including owners and boards in the matter of organizational innovations, a finding that has not been emphasized in earlier research. In fact, very little has been written overall about boards' roles in the creation, diffusion, and sustaining of organizational innovations. The empirical finding in Alänge and Steiber (2009), however, was that boards affect the sustaining of major organizational innovations. They identified a number of issues critical for creating board commitment for sustaining a major organizational innovation: board competence and experience, board meeting dynamics, provider of critical resources, and the process for replacing CEOs. However, underlying theories (Principal-Agency theory, Stewardship theory, and Resource Dependence theory) on how to best govern a firm or other organizations were found to affect boards' perceptions of their mission and main roles. The dominant theory, Principal-Agency theory, may negatively affect boards' involvement in, and commitment to, sustaining a major organizational innovation, while the other two theories enable both a closer relationship between the board and CEO, and more active board roles, such as, for example, the role as a resource provider. In fact, boards could have an important role to play not only in sustaining an organizational innovation, or trajectory, but also in the creation and diffusion of organizational innovations. Boards can be assumed to affect investment decisions on any innovation, and to provide access to resources and networks, and thereby facilitate inter-firm diffusion of ideas. Finally, boards can ensure macro-stability when organizational innovations require many years to be fully implemented. According to Alänge and Steiber (2009), a board must therefore have insight into how it affects the sustaining of implemented organizational innovations. Further, a board must view itself as an organizational body that can and must provide critical resources to the firm/organization. As a consequence, a board must proactively gather knowledge about the firm/organization and its industry and create an effective board group and work processes based on norms that support a strategic, collaborative, innovative, and open environment within the board and between the board and CEO. In addition, a board must take responsibility for creating a process that ensures a certain organizational trajectory can be sustained in case the CEO is replaced.

\section{A comprehensive model}

Based on the literature reviews and input from the two empirical studies (Alänge and Steiber 2009, 2011) with a longitudinal perspective, we will now introduce a comprehensive model for the creation, diffusion, and sustaining of organizational innovations. 
As the creation, diffusion, and sustaining of an organizational innovation can be viewed as three intertwined concepts, they should not be explored in isolation. Therefore, in order to study these three aspects in an integrated way, a comprehensive model is suggested. This model includes five steps: desirability, feasibility, first trial, implementing, and sustaining. These five steps are subject to three sets of influencing factors: set 1 , the characteristics of the innovation itself; set 2, the internal context; and set 3 , the external context and diffusion channels. Further, each step is influenced by triggers, visualized as flashes in the model. The triggers could be valid for one or several steps. The model and its main components are presented in Fig. 1.

Drawing the model as a static, two-dimensional linear model creates a dilemma, since the creation, diffusion, and sustaining of organizational innovations are not linear concepts but rather are highly intertwined, due to the fact that the innovation is constantly re-invented. For this reason, it is necessary to add a dynamic perspective to the model. In Fig. 1, the five steps desirability, feasibility, first trial, implementing, and sustaining are therefore visualized as a circular pattern around an organizational improvement trajectory. The re-invention of the innovation is path-dependent and cumulative due to internal inertia among top managers and employees. Thus, the desirability and perceived feasibility of a new organizational innovation as well as the decisions if to trial and if to implement are affected by previously chosen organizational innovations. In cases where a follow-up innovation substitutes or competes with an implemented organizational innovation, a totally new organizational improvement trajectory may result. Therefore, the concept of "sustaining" does not refer to a particular organizational innovation, but rather to an organizational improvement trajectory. This trajectory is also influenced

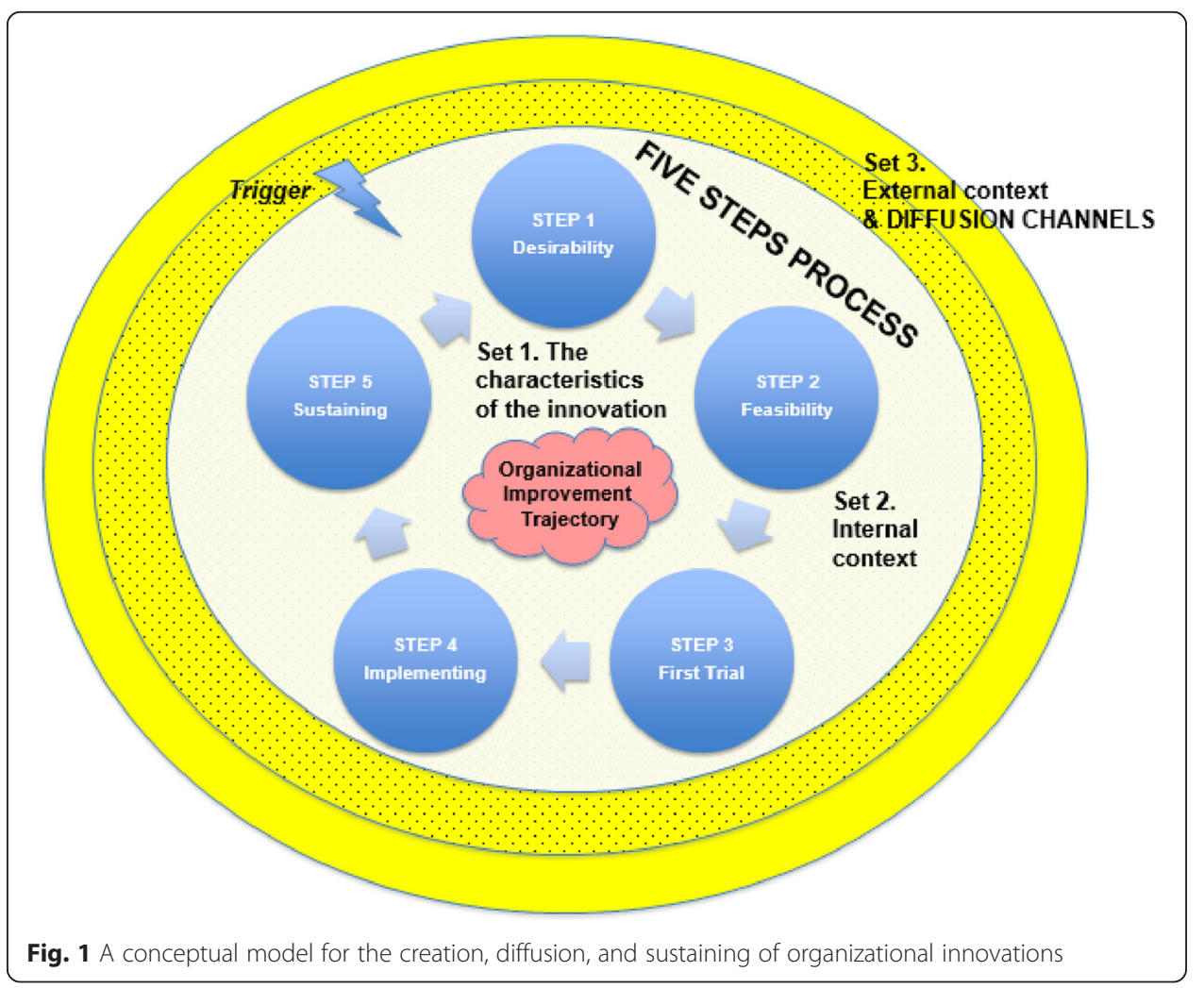


by the organization's inertia and path dependency and thus affects the search and learning processes for future organizational innovations.

On a national and even international level, there are organizational improvement trajectories as well, where organizational innovations diffuse between firms or organizations and are gradually re-invented, and at a certain point in time are challenged by new organizational innovations based on a new way of thinking in management (Lundgren and Alänge 2000; Alänge and Steiber 2011). When national/international improvement trajectories are based on complex organizational innovations, such as TQM and Lean, there can also be a considerable overlap in terms of content between parallel trajectories. These national/international improvement trajectories naturally have a considerable influence on an individual organization's improvement trajectory (Alänge and Steiber 2011).

The inner circle in Fig. 1 represents the internal context in an organization. Here, the top management and the board are crucial for sustaining, and also in some cases creating, the improvement trajectory. Top management's own inertia, user competence, and commitment to the innovation and the organizational improvement trajectory are important and can either limit or increase the internal inertia/path dependency and resistance towards change. Here, top management can use communication, for example, in the form of narratives and road maps to limit internal inertia and resistance to a desired organizational change. Further, the search and learning processes are cumulative and path-dependent, but could break potential inertia by becoming more conscious and systematic in the desirability and feasibility steps.

The two outer circles represent the external context and diffusion channels that transfer knowledge and experience into the organization. The outermost circle area depicts the external environment in the form of institutional setup, local norms, history, and existing weak ties that the organization has through its employees with networks that are active outside the local context. The external environment also represents factors such as the sector characteristic competitive pressure and dynamic, due to e.g. pace in technological development. The dotted area represents diffusion channels such as movement of people (including CEOs), boards, user networks, bridging institutions, universities, and consultants. These diffusion channels could all play a role in "showing" and "proving" what is desirable and feasible.

The triggers (visualized as flashes in Fig. 2) for each step in the five-step process could typically be a perceived crisis, a new market or owner demand (which in turn could have been triggered by technological development and lower entry barrier in a certain sector), imitation of organizational concepts developed by other companies in the user network, management previous experience and beliefs in the innovation, standardization work done by bridging institutions, consultants and university professors, and management fads. An example of a trigger that influences several steps is "management beliefs," which in turn is partly based on management's experience of the innovation. An example of a trigger that was found to be more related to a single step was "consultant experience," which was commonly found in the first trial step and less so in earlier or later steps.

The comprehensive model, now including all factors mentioned in the discussion above, is presented in Fig. 2.

As could be seen in the comprehensive model in Fig. 2, an organization is triggered by e.g. a new market or owner demand or a perceived crisis (triggers: text in italics). 


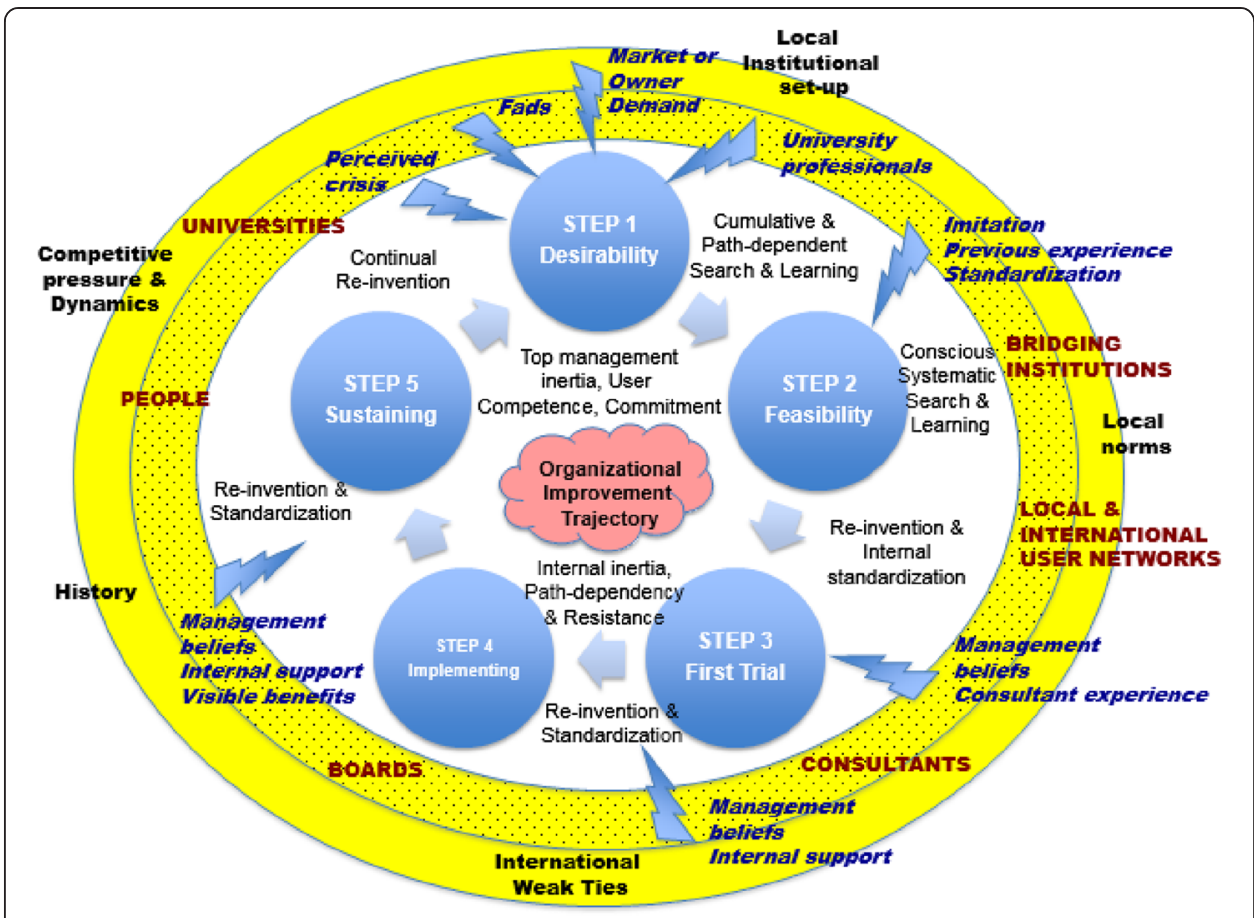

Fig. 2 A comprehensive model for the creation, diffusion, and sustaining of organizational innovations

This in turn creates a desire to conduct an organizational development and change. The search and learning process for feasible organizational concepts, e.g., Lean Production or TQM, is cumulative, path-dependent, and to a certain degree conscious and systematic. The search and learning process is triggered and influenced by managers' previous experience, imitation of other organizations (often with a low organizational distance), earlier adopted and implemented organizational innovations (inertia and path dependency), and also the characteristics of the new innovation as such, e.g., if it is well standardized and therefore is easier to "observe." However, also external factors such as history, local norms, competitive pressure, and the so-called weak ties (see the outermost circle in Fig. 2) could affect perceived "feasibility" of the new innovation. The institutional setup influence as well as knowledge and experience of universities and consultants and the work of bridging organizations matter as "diffusion channels" (see uppercase text in dotted circle). When the organization perceives a certain organizational innovation as feasible, the next step is to conduct a first trial. In this step, the innovation is partly re-invented and internally standardized in order to better fit with the specific organization. Factors such as user competence, inertia, and path dependency in the internal context are affecting this re-inventing process. In this step, university professionals and consultants could play an important role as a trigger and as a diffusion mechanism for knowledge and experience of the new innovation. Based on lessons learned during first trial, the innovation is once again re-invented and internally standardized, which makes an implementation possible as it reduces resistance to change. However, also during implementation, internal inertia and path dependency are influencing how the new innovation is re-invented and standardized. The process of continuous re-invention and standardization of the new innovation is continuing throughout implementation and later in order to sustain the implemented innovation. 
During these two steps "implementing" and "sustaining," management beliefs on the innovation do play an important role. Visible benefits from the new innovation are important in order to strengthen management beliefs and increase internal overall support for change. Boards as a diffusion mechanism for knowledge and experience of new organizational innovations could play an important role as both an initial trigger to organizational change and for sustaining an implemented change in the organization. For this reason, the user competence among board members regarding the new organizational innovation and their belief in its business value for the organization is important (Alänge and Steiber 2009).

As commented upon in the "Methodology" section, the framework presented in Fig. 2 was used in a study for the Swedish Innovation agency "VINNOVA" (a comparative analysis of seven European and North American national/international programs for the dissemination of organizational innovations contributing to increased competitiveness among existing firms). This study (Steiber and Alänge 2013a) showed that the framework was useful for analyzing both similarities and differences between the seven different programs. For example, the five steps in the intra-firm diffusion process were all valid and relevant when analyzing a program's design (see Fig. 2). Steps such as "Desirability" and "Feasibility" were in several programs positively influenced by strategically designed awareness activities and training for (potentially) participating organizations and their managers. Issues such as user competence, inertia, and path dependency on an organizational level also affected the "Desirability" and "Feasibility" steps. For this reason, some of the programs choose to actively promote the disseminated organizational innovation as a concept that "complements" the adopting organization's existing product development process, rather than "replacing" it. Further, the external context, such as history, culture, and local institutional setup, influenced the dissemination of the specific organizational innovation. In fact, the local resources' part of the institutional setup showed to play a crucial role in the dissemination of the specific organizational innovations. In most cases, these local resources, e.g., in the form of consultants, research institutes, and industry associations, needed both education and training, even in cases when the organizational innovation was more standardized, such as Lean Production. Finally, the primary diffusion mechanisms identified in the seven programs were universities, consultants, people, user networks (role models), research institutes, and industry associations. However, also local governmental organizations as well as non-profit organizations showed to play a role as diffusion channels.

Seen from a triple helix perspective, any organization from either one helix (industry, university, or government) has its own improvement trajectory, which is influenced by other organizations (and their improvement trajectories) both from within the same and other helices. During dissemination processes, there is a need for a certain degree of regional/national agreement (or consensus space, cf. Etzkowitz and Ranga 2012) concerning the characteristics of organizational innovations (such as TQM or Lean) and of their dissemination processes. In the case this regional/national agreement or consensus space exists between key actors from the three helices, the regional or national dissemination process for a certain organizational innovation could be expected to become more effective. The Triple Helix dynamics could therefore be expected to directly influence the effectiveness of the creation, diffusion, and sustaining of an organizational innovation. Further, the Triple Helix dynamics could be assumed to play 
an even more important role in the case the new organizational innovation is hard to observe and test; when it is complex, that is, it affects most parts of a firm or organization; when the knowledge about the new innovation is low among players in the institutional setup, e.g., universities and consultants; and where there is a low compatibility between the new innovation and what has been previously adopted and implemented by firms and organizations in the specific region or nation.

One illustrative example, of how a Triple Helix dynamics benefitted the dissemination of a complex organizational innovation, is the initiation of the "Production Leap," one of the seven programs investigated in the VINNOVA study (Steiber and Alänge 2013a). This program was initiated by a combination of actors-the Royal Academy of Engineering Sciences, a labor union and an employer organization-becoming aware of the increased international competition for small- and medium-sized enterprises (SMEs) and reaching consensus of a need for a national program to disseminate "Lean Production" to Swedish SMEs. The characteristics of this organizational innovation and of its dissemination process showed to be in continual development through various collective learning processes and hence can be described as a trajectory not only on a regional/national level but also on a program level (Steiber and Alänge 2013a).

\section{Conclusions and future research}

The purpose of this paper was to develop a comprehensive model for studying and better understanding the creation, diffusion, and sustaining of organizational innovations by using a system perspective. One important finding is that previous research, including our own from several empirical case studies, clearly converges towards certain "steps" in an organizational change process, as well as to certain "sets of influencing factors" that can support or hinder the inter-firm and intra-firm dissemination process of an organizational innovation.

A first conclusion is therefore that the model could be visualized as five steps (desirability, feasibility, first trial, implementing, and sustaining) that are in turn influenced by three main sets of influencing factors: the characteristics of the innovation itself, the internal context, and the external context together with different types of diffusion channels transferring knowledge from external sources to the organization.

However, drawing the model as a static, two-dimensional linear model creates a dilemma, which leads us to our second conclusion, namely that the creation, diffusion, and sustaining of organizational innovations are not linear, sequential concepts but rather are highly intertwined, due to the fact that the organizational innovation is constantly re-invented. For this reason, it does not make sense to speak of or study each concept in isolation as both Birkinshaw et al. (2008) and Buchanan et al. (2005) did.

The third conclusion is that the concept "sustaining" of organizational innovations refers to an organization's improvement trajectory, rather than to a particular organizational innovation. This means that a major organizational innovation such as TQM exists therefore over time in several "releases" in an adopting organization. Each release is valid only temporarily, since it is constantly re-invented as a result of continuous external and internal triggers for change. Further, the improvement trajectory is path-dependent and cumulative due to internal inertia among top managers and employees, so the decision to adopt new organizational innovations is affected by the historically chosen ones. 
Finally, national or even international organizational improvement trajectories (both TQM and Lean and potentially in the future "Innovation Management" are all examples of major organizational innovations that have been key concepts in international and national organizational improvement trajectories) naturally have a considerable influence on an individual organization's improvement trajectory (Alänge and Steiber 2011).

This paper is planned to be the first of two. The follow-up paper will serve the purpose of verifying the model developed in this paper by testing it on another type of organizational innovation, different from TQM, TPS, and Lean that were studied in Alänge and Steiber $(2009,2011)$. By doing this, we can verify if the characteristics of an organizational innovation affect the applicability of the comprehensive model. TQM, TPS, and Lean were all developed in a context of continuous improvement with the aim of achieving quality and efficiency, and they all draw strongly on the experiences of Toyota in Japan. The organizational innovation chosen for the follow-up paper is the Google Model, which focuses primarily on continual innovation and has been developed in the Internet industry in Silicon Valley, USA. In recent years, the Google Model has been branded as a unique management model, and publications such as "The Google Way: How One Company is Revolutionizing Management As We Know it” (Girard 2009), "Googled: The End of the World as We Know It" (Auletta 2009), and "A Corporate System for Continuous Innovation: The case of Google Inc." (Steiber and Alänge 2013b) support a picture of the Google Model as an organizational innovation.

The suggestion for future research is to further validate and refine this more comprehensive model by testing it not only on more types of organizational innovations but also on more types of organizations, e.g., within the university and government helices. In addition, there is a need to identify the importance of differences in underlying institutional environments by testing it in other countries than Sweden.

It would also be valuable to further explore the value of using a concept such as an organizational improvement trajectory to explain a firm's or other organizations' organizational development, and its conscious and unconscious choices when adopting organizational innovations.

Finally, it would be of value to further test the model by using other perspectives, e.g., an open innovation perspective where organizational innovations might be created, diffused, and/or sustained either as a result from a learning process when a firm or organization is co-creating collaboratively with external partners, or as a direct result from the co-creation and collaboration process. In addition, Steiber and Alänge (2013a) indicate that the Triple Helix dynamics do influence the dissemination process of organizational innovations. It would therefore also be of value to test how the Triple Helix dynamics influence the creation, diffusion, and sustaining of organizational innovations.

\section{Endnotes}

${ }^{1}$ This part of the research literature is using a national or regional innovation system perspective, i.e., the same perspective as we have chosen (together with a rational perspective); see the "The creation and diffusion of organizational innovations" section. Research literature using other perspectives, e.g., an open innovation or more general co-creating and knowledge networking perspective, e.g. Savage 1996 (Fifth Generation 
Management), Amidon 1997 (Knowledge Innovation), and Mercier-Laurent 2011 (Innovation Ecosystems), were not included in this review of literature on the creation, diffusion, and sustaining of technical innovations.

${ }^{2}$ In Alänge et al. (1998), organizational innovation was found hard to separate from inter-firm diffusion as it was constantly re-invented/re-created during the diffusion process. This was also the case in the intra-firm diffusion process, with respect to implementing and sustaining the organizational innovation.

${ }^{3}$ In this paper, the concepts "organizational innovations," "administrative innovations," and "managerial innovations" are used interchangeably.

${ }^{4}$ However, important to notice is that an organizational innovation that is "new to the organization" still can be disruptive, e.g., for the specific industry that the organization act in. In addition, a "new to the organization" innovation can support both incremental and more disruptive technical innovations developed and implemented by the organization. One such example is the dissemination, adaptation, and implementation of methods and tools for "Innovation Management." Broadly, Innovation Management could be viewed as how to manage and organize not only for a more effective innovation process but also for securing a higher level of impact from generated innovations. The optimal case is when an organization can generate both incremental and disruptive innovations.

${ }^{5}$ The model is based on an earlier model by Birkinshaw and Mol (2006). However, this previous model separated motivation into two steps-dissatisfaction with the status quo and inspiration-which the authors claimed usually comes from outside the firm. Further, the model did not include an "implementation" step.

${ }^{6}$ In Alänge et al. (1998), it was found that innovation and diffusion cannot be distinguished in a meaningful way, but that the diffusion curve should be seen as an envelope curve, superimposed with a number of minor diffusion curves.

\section{Additional file}

Additional file 1: Translation of the abstract into Arabic.

Received: 5 January 2015 Accepted: 18 May 2015

Published online: 04 June 2015

\section{References}

Abrahamson E (1996) Management fashion. Acad Manage Rev 21(1):254-285

Akgün AE, Byrne JC, Lynn GS, Keskin H (2007) Organizational unlearning as changes in beliefs and routines of organizations. J Organ Change Manage 20(6):794-812

Alänge S (1992) Total Quality Management as a tool for organizational change - the case of Motorola. CIM Working Papers WP 1992:01

Alänge S (1994) The new paradigm for industrial practices: Total Quality Management in 1994. CIM Working Papers WP 1994-01

Alänge S, Steiber A (2009) The board's role in sustaining major organizational change - an empirical analysis of three change programs. Int J Qual Serv Scie 1(3):280-293

Alänge S, Steiber A (2011) Diffusion of organizational innovations: an empirical test of an analytical framework. Technol Anal Strateg Manage 23(8):881-897

Alänge S, Jacobsson S, Jarnehammar A (1998) Some aspects of an analytical framework for studying the diffusion of organizational innovations. Technol Anal Strateg Manage 10(1):3-21

Amidon DM (1997) Innovation strategy for the knowledge economy: the Ken awakening. Butterworth-Heinemann, Newton, MA

Auletta K (2009) Googled: the end of the world as we know it. The Penguin Press, New York

Bayerl PS, Jacobs G, Denef S et al (2013) The role of macro context for the link between technological and organizational change. J Organ Change Manage 26(5):793-810

Berendse M, Duijnhoven H, Veenwijk M (2006) Editing narratives of change: identity and legitimacy in complex innovative infrastructure organizations. Interv Res 2(1-2):73-89 
Bessant J, Rush H (1995) Building bridges for innovation: the role of consultants in technology transfer. Res Policy 24:97-114

Birkinshaw J, Mol M (2006) How management innovation happens. MIT Sloan Manage Rev 47(4):81-88

Birkinshaw J, Hamel G, Mol MJ (2008) Management innovation. Acad Manage Rev 33(4):825-845

Brown SL, Eisenhardt KM (1997) The art of continuous change: linking complexity theory and time-paced evolution in relentlessly shifting organizations. Adm Sci Q 42:1-34

Brown SL, Eisenhardt KM (1998) Competing on the edge: strategy as structured chaos. Harvard Business School Press, Boston

Buchanan D, Fitzgerald L, Ketley D, Gollop R, Jones JL, Lamont SS, Neath A, Whitby E (2005) No going back: a review of the literature on sustaining organizational change. Int J Manage Rev 7(3):189-205

Carlsson B, Jacobsson S (1994) Technological systems and economic policy: the diffusion of factory automation in Sweden. Res Policy 23:235-248

Carlsson B, Stankiewicz R (1991) On the nature, function, and composition of technological systems. J Evol Econ 2(1):93-118

Cooke P (2001) Regional innovation systems, clusters, and the knowledge economy. Oxford University Press, Oxford, pp 945-974

Cummings LL, O'Connell MJ (1978) Organizational innovation: a model and needed research. J Bus Res 6:33-50

Dubois A, Gadde L-E (2002) Systematic combining: an abductive approach to case research. J Bus Res 55(7):553-560

Edquist C (1992) Technological and organizational innovations, productivity and employment. World Employment Programme Research Working Paper WEP 2-22/WP 233 http://www.lo.org/public/libdoc/ilo/1992/92B09_223_ engl.pdf Accessed 17 November 2013

Ehrnberg E, Jacobsson S (1991) Technological discontinuities, industry structure and firm strategy - the case of machine tools and flexible manufacturing systems. Department of Industrial Management and Economics, Chalmers University of Technology, Gothenburg

Etzkowitz H, Leydesdorff L (1995) The Triple Helix: university-industry-government relations. A laboratory of knowledge based economic development. EASST Rev 14(1):11-19

Etzkowitz H, Ranga M (2012) 'Spaces': a triple helix governance strategy for regional innovation. In: Rickne A et al (eds) Innovation governance in an open economy: shaping regional nodes in a globalized world. Routledge, London, pp 51-68

Frambach RT, Schillewaert N (2002) Organizational innovation adoption - a multi-level framework of determinants and opportunities for future research. J Bus Res 55:163-176

Freeman C (1982) The economics of industrial innovation, 2nd edn. Frances Pinter, London

Freeman C (1987) Technology policy and economic performance: lessons from Japan. Pinter Publications, London

Ganter A, Hecker A (2013) Deciphering antecedents of organizational innovation. J Bus Res 66:575-584

Ganter A, Hecker A (2014) Configurational paths to organizational innovation: qualitative comparative analyses of antecedents and contingencies. J Bus Res 67:1285-1292

Girard B (2009) The Google WAY: how one company is revolutionizing management as we know it. No Starch Press, San Francisco

Granovetter MS (1973) The strength of weak ties. Am J Sociol 78:1360-1380

Hamel G (2006) The why, what, and how of management innovation. Harv Bus Rev 84(2):72-84

Jarnehammar A (1995) Towards a framework for analysing the diffusion of organizational innovations. Licentiate dissertation, Chalmers University of Technology, Gothenburg

Kimberley JR (1979) Issues in the creation of organizations: initiation, innovation, and institutionalization. Acad Manage J 22(3):437-457

Kimberley JR (1981) Managerial innovation. In: Nystroem PC, Starbuck WH (eds) Handbook of organisational design. Oxford University Press, New York

Langstrand J, Elg M (2012) Non-human resistance in changes towards lean. J Organ Change Manage 25(6):853-866

Leonard-Barton D (1988) Implementation as mutual adaptation of technology and organization. Res Policy 17:251-267

Leonard-Barton D (1992) Core capabilities and core rigidities: a paradox in managing new product development. Strateg Manage J 13(Special Issue):111-125

Liker JK (2004) The Toyota way: 14 management principles from the world's greatest manufacturer. McGraw-Hill, New York Lounsbury M, Crumley ET (2007) New practice creation: an institutional perspective on innovation. Organ Stud 28:993-1012 Lundgren R, Alänge S (2000) Diffusion of organisational innovations - quality management in Sweden. CIM Working Papers WP 2000:02

Lundvall B-Å (ed) (1992) National systems of innovation: towards a theory of innovation and interactive learning. Anthem Press, London

Lynch LM (2007) The adoption and diffusion of organizational innovation: evidence for the US economy. IZA Discussion Paper No. 2819

Mercier-Laurent E (2011) Innovation ecosystems. John Wiley \& Sons, Hoboken, NJ

Mol MJ, Birkinshaw J (2009) The sources of management innovation: when firms introduce new management practices. J Bus Res 62:1269-1280

Nelson R (ed) (1993) National innovation systems - a comparative analysis. Oxford University Press, New York

OECD (2005) Oslo manual: guidelines for collecting and interpreting innovation data, 3rd edn. http://www.keepeek. com/Digital-Asset-Management/oecd/science-and-technology/oslo-manual_9789264013100-en\#page51 Accessed 1 November 2013

Porter M (1990) The competitive advantage of nations. Macmillan, London

Rogers EM (1995) Diffusion of innovations, 4th edn. Free Press, New York

Rosenberg N (1976) Perspectives on technology. Cambridge University Press, Cambridge, MA

Savage CM (1996) 5th Generation management: co-creating through virtual enterprising, dynamic teaming, and knowledge networking, revised edition. Butterworth-Heinemann, Woburn, MA

Saxenian AL (1996) Regional advantage: culture and competition in Silicon Valley and Route 128. Harvard University Press, Boston 
Shiba S, Walden D, Graham A (1993) A new American TQM: four practical revolutions in management. Taylor \& Francis, Oxford Simon H (1979) Rational decision making in business organization. Am Econ Rev 69(4):493-513

Steiber A (2012) Organizational innovations: a conceptualization of how they are created, diffused and sustained. PhD dissertation, Chalmers University of Technology, Gothenburg

Steiber A, Alänge S (2013a) Diffusion of organisational innovations: learning from selected programmes. Vinnova Report VR 2013:07, Vinnova (Swedish Governmental Agency for Innovation Systems), Stockholm

Steiber A, Alänge S (2013b) A corporate system for continuous innovation: the case of Google Inc. Eur J Innov Manage 16(2):243-264

Strang D, Meyer JW (1993) Institutional conditions for diffusion. Theory Soc 22:487-511

Teece D (1980) The diffusion of administrative innovation. Manage Scie 26:464-470

Teece D (2007) Explicating dynamic capabilities: the nature and microfoundations of (sustainable) enterprise performance. Strateg Manage J 28:1319-1350

Tichy NM (1983) Managing strategic change: technical, political and cultural dynamics. John Wiley \& Sons, New York

Tushman ML, O'Reilly C III (1997) Winning through innovation: a practical guide to leading organizational change and renewal. Harvard Business School Press, Boston

Volberda HW, Van den Bosch FAJ, Heij CV (2013) Management innovation: management as fertile ground for innovation. Eur Manage Rev 10:1-15

Womack JP, Jones DT (2003) Lean thinking: banish waste and create wealth in your corporation, 2nd edn. Simon Schuster, London

Wright C, Sturdy A, Wylie N (2012) Management innovation through standardization: consultants as standardizers of organizational practice. Res Policy 41:652-662

Submit your manuscript to a SpringerOpen ${ }^{\circ}$ journal and benefit from:

- Convenient online submission

- Rigorous peer review

- Immediate publication on acceptance

- Open access: articles freely available online

- High visibility within the field

- Retaining the copyright to your article

Submit your next manuscript at $\boldsymbol{\nabla}$ springeropen.com 